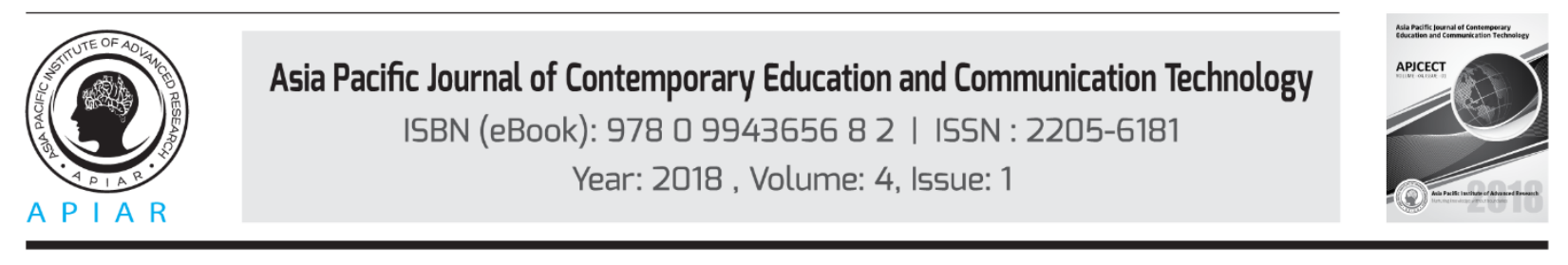

\title{
SMARTPHONE APPLICATION FOR INCREASING ENGLISH CULINARY VOCABULARY
}

\author{
Aryo Baskoro Utomo a, Sita Nurmasitah b \\ ab Universitas Negeri Semarang, Indonesia \\ Corresponding email: aryobaskoro@mail.unnes.ac.id
}

\begin{abstract}
The rapid growth of technology creates various sophisticated facilities in order to make things easier in life. Along with the development of technology, globalization requires good, skilled workforce. Vocational institutions in Indonesia areexpected to produce high quality graduates, so that they can compete in global market. One of the efforts to achieve this goal is giving the students an English subject. English subject is given to the students based on their specific study program, so called English for Specific Purposes (ESP). Based on the observation, English subject is usually taught only 100 minutes per week on average. The students need more time to learn and practice the language. Moreover, they usually prefer having practical and fun language learning. Recently, the smartphone is a necessary device that grow more countless and complex every day. Interactive android application in smartphones can be an alternative for the students to have language self-study. Based on aforementioned reasons, this research aims to design smartphone android application for culinary program students. The stages of the research are; (1) collecting data, (2) designing the application flow chart, and (3) designing the layout.
\end{abstract}

Keywords: Interactive Android Application, English Language Learning, Culinary Program.

\section{Introduction}

Entering the era of globalization, English becomes an international language and plays an important role in every aspect of life. In education, English is recognized as a doorway to better education and a great job opportunities (Ahmad, 2016). English is taught and learned as a second language or a foreign language around the world (Sekhar \& Chakravorty, 2017). In Indonesia, English is not a second official language in Indonesia, but it is appointed as a foreign language (Braine, 2014). Therefore, many Indonesians learn English in order to be able to communicate effectively with each other in this era of globalization.

Panggabean (2015) stated that in Indonesia, learning and teaching English is conducted in formal schools and is started from early education to university levels. In elementary level, English has been taught as an elective subject in some Primary Schools. However, several schools implement the compulsory subject of English in their curriculum. Moreover, English is a compulsory subject for three years at Junior High Schools and for three years in Senior High Schools (Mattarima \& Hamdan, 2016). In the university level, English is taught as a compulsory subject in non-English department. Students are required to take English subject in the beginning of their semester at college. They engage in English learning activity for one or two semesters. 
English subject in higher education, especially in non-English department, corresponds to the purpose of its graduates, so called as English for Specific Purposes (ESP). International Teacher Training Organization in Bracaj (2014) defines ESP as a term that refers to teaching or studying English for a particular career (like law, medicine) or for business in general. Moreover, Bracaj suggests that General English sometimes does not meet the needs of the learners since they have certain objectives of learning English. People in non-English speaking countries, including Indonesia, study English for some reasons, such as to fulfill the compulsory subject requirement, to pass the English proficiency tests, or to acquire better work opportunities. Thus, English subject in higher education can be described as ESP to meet the purpose of the students' needs of future career.

In Indonesia, the students in non-English department are usually required to take English subject on the first semester. The first semester of studying English is considered to help the students' in understanding the underlying knowledge of their major study. Moreover, the general objectives of ESP in non-English department are; (1) the students have competencies in English language skills (listening, speaking, reading, and writing) and demonstrate daily communication in English, (2) The students understand basic terminology of their major study and apply them on the communication using English. From the objective, it seems that English plays an important role since students will find out a lot vocabulary or terms in foreign languages, including English, during their study.

Teaching ESP definitely has several obstacles in its implementation. Marwan (2017) concluded that there are several issues of teaching ESP, such as; the student's low motivation and lack of proficiency, lack of quality teaching and learning resource, large class size, and a heavy workload of the teacher. Moreover, Panggabean (2015) also stated that the students only spend less than two hours in a week in the classroom to have English subject. They are actively using English as a means of communication only in a classroom. It means that they do not have enough time to practice their English.

Getting in touch with the development of technology, the constraints of teaching ESP can be diminished. Students are excited to use mobile devices, which can be the motivation for students in learning (Ciampa, 2014). Furthermore, Sivakumar (2015) suggested that with mobile devices, students may learn in any place, any time, and also have the opportunity to increase their English. With the limited time of English subject in the classroom, they still have an extra time outside of the class to practice using the enjoyable mobile devices.

One of mobile devices which is recently highly utilized by the students is a smartphone. Its ability to support mobile applications becomes a popular function among the users (Mindog, 2016). In a fact, there are several English language learning application and games are available to download without being charged from the Google play store or Apple's application store (Sivakumar, 2015).

Several previous studies about mobile language learning were investigated by $\mathrm{Oz}(2015)$ in Turkey, Sivakumar (2015) in India, Wu (2015) in China, and Mindog (2016) in Japan. They revealed a good improvement usage or design of apps in smartphone for learning English. However, all their research designs provide the material for general English. They have not improved the ESP material for practical use in the smartphone.

This research aims to design interactive smartphone application for culinary program students, more focusing on the vocabulary learning. Why vocabulary? Because vocabulary is the core and the first important step of learning language. Madarsara (2015) stated that language significantly contributes to the comprehension level. Hatch and Brown in Mokhtar et al (2017) suggested that there are five steps involved in language learning: dealing with the new words, 
obtaining the word form, knowing the word meaning, combining the word form and meaning in memory, and using the word. Moreover, Nation (2013) stated two categories of vocabulary acquisition strategies; incidental vocabulary learning and intentional vocabulary learning. Incidental learning refers to learning language vocabulary through special context, while intentional learning means another way of learning. Wu (2015) concluded from previous research that the foreign language learners refer to intentional vocabulary learning because the new vocabularies are hard to understand and they need some times to correctly use in the right context.

This design of application attempts to provide practical and fun vocabulary learning through some explanation and vocabulary games. Claxton in Ghanbaran \& Ketabi (2014) suggested that multimedia games can be a stimulation for students and also give them an opportunity to have self-learning by playing games. This research tries to develop intentional vocabulary learning trough smartphone application and it is expected to increase the ability of the students in mastering vocabulary in terms of culinary field.

\section{Method}

The process of designing the application was organizing through several steps; (1) collecting data to find out the information about the ESP class in culinary education program by giving questionnaire and interviewing the lecturer and the students, (2) designing the application content material, and (3) designing the layout.

Questionnaires and interviews wereused as a data instrument collection of the research. Sixty students in two classes of culinary education program at Universitas Negeri Semarang, Indonesia was investigated in order to examine the students' need for mobile learning in the class. The questionnaire was adapted and modified from Kirovska-Simjanoska (2017). It used Likert scale to find out the usage of smartphones to learn English. Two students as a sample for each class were interviewed to gain more explanation related to the questionnaire.

Moreover, interviewing the English lecturer was conducted to discover the syllabus, material used, an also the obstacles in the teaching and learning process.

In designing the application, the Android smartphone application was chosen because in 2017 the statistics shows in Figure 1, 76.11 million Indonesian people accessed the internet through their smartphone. Moreover, based on the results of a survey conducted by Cint on the types of operating systems used on smartphones for personal purposes in Indonesia, 65.8 percent of Indonesian respondents stated they use Google Android on their smartphone as shown in Figure 2 (Statista, 2017).

Furthermore, the design of the application was processed by using Audacity, CorelDraw, and Adobe Flash CS6 X7 software. Audacity is a free open source multilingual audio editor and recorder computer software that is used to record and edit sounds in the application. Sounds wereadded to the vocabulary explanation so the users were aware on its pronunciation. The graphics in the application was designed by using CorelDraw. Then, Adobe Flash CS6 X7 was used to create vocabulary games that responds to users interaction. 


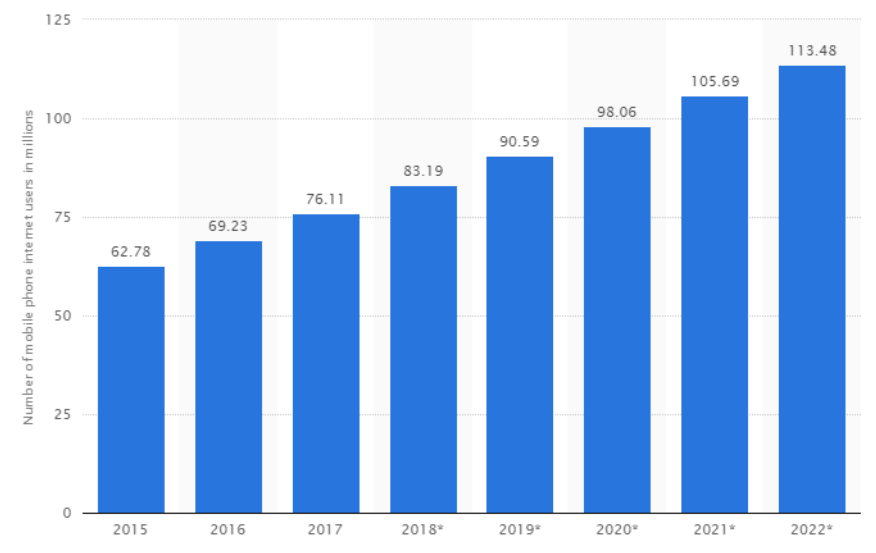

Figure 1: Smartphone Internet Users in Indonesia

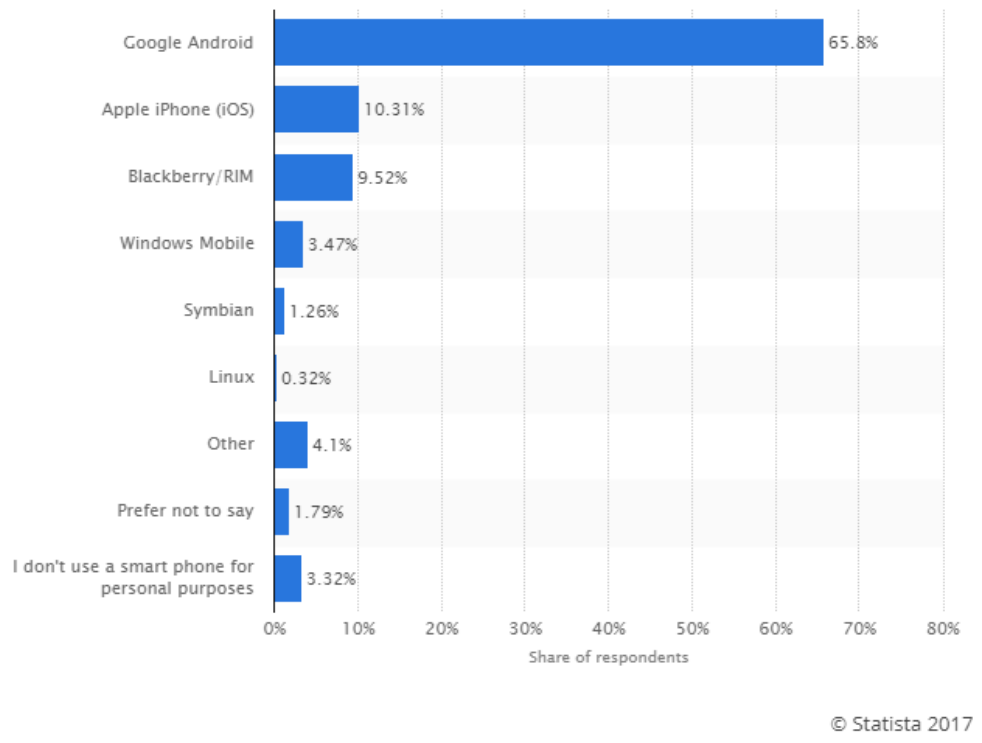

Figure 2: Operating System in Indonesia

\section{Discussion}

\section{The Usage of Smartphone to Learn English}

Sixty students of culinary education program at Universitas Negeri Semarang, Indonesia were requested to respond several statements related to the usage of smartphone to learn English related to their major study on a scale from $1-5(1=$ never; $2=$ very rarely; $3=$ rarely; $4=$ often; 5 = very often). The response of the students are summarized in the Table 1.

The result of the questionnaire and interview shows that most of the students use smartphones for searching complementary information on internet and navigating on website that are classrelated, especially when they have to do exercise or homework. Moreover, they also use online or offline translator in smartphone to help them translate the difficult words. However, based on the students' interview, small number of students play game that are class-related because most ( $)$ of them experienced the difficulties in finding the class-related games. They usually download and use an application or game for learning general English. In this case, the students admitted the effectiveness of playing game, especially vocabulary game, for increasing their English vocabulary. 
Table 1: The Usage of Smartphone to Learn English

\begin{tabular}{|c|c|c|c|c|c|c|}
\hline No & Smartphone Usage & Never & $\begin{array}{l}\text { Very } \\
\text { rarely }\end{array}$ & Rarely & Often & $\begin{array}{l}\text { Very } \\
\text { often }\end{array}$ \\
\hline 1 & $\begin{array}{l}\text { Use online or offline dictionary in } \\
\text { smartphone }\end{array}$ & & & & $45 \%$ & $55 \%$ \\
\hline 2 & $\begin{array}{l}\text { Search complementary information on } \\
\text { internet }\end{array}$ & & & $15 \%$ & $25 \%$ & $60 \%$ \\
\hline 3 & $\begin{array}{l}\text { Navigate on websites that are class- } \\
\text { related }\end{array}$ & & & $10 \%$ & $35 \%$ & $55 \%$ \\
\hline 4 & Take notes on the phone & & & $40 \%$ & $35 \%$ & $25 \%$ \\
\hline 5 & Visit social media & & $30 \%$ & $25 \%$ & $45 \%$ & \\
\hline 6 & Take a picture and video & & & $20 \%$ & $55 \%$ & $25 \%$ \\
\hline 7 & Record voice & & $35 \%$ & $25 \%$ & $30 \%$ & $10 \%$ \\
\hline 8 & $\begin{array}{l}\text { Download and use application to learn } \\
\text { English }\end{array}$ & & $30 \%$ & $50 \%$ & $20 \%$ & \\
\hline 9 & Check pronunciation of vocabulary & $15 \%$ & $35 \%$ & $30 \%$ & $20 \%$ & \\
\hline 10 & $\begin{array}{l}\text { Join online messenger group to learn } \\
\text { English }\end{array}$ & $40 \%$ & $40 \%$ & $20 \%$ & & \\
\hline 11 & Play game that are class-related & $50 \%$ & $35 \%$ & $15 \%$ & & \\
\hline 12 & Send emails & & & $40 \%$ & $45 \%$ & $15 \%$ \\
\hline
\end{tabular}

\section{Teaching ESP in Culinary Education Program}

English subject in culinary education program at Universitas Negeri Semarang, Indonesia is a compulsory subject for the first semester students. They have 100 minutes in a week for one semester to learn specific purpose of English related to their major study, culinary. Based on its syllabus, at the end of semester, the students are expected to have competencies in English language skills; listening, speaking, reading, and listening. Moreover, the students have to understand basic terminology of culinary and apply them on the English communication. Hence, the English lecturer in culinary education program always put topics related to culinary field on the list of material. Table 2 describes the lesson topic created by the English lecturer.

The list of the lesson topics in culinary program provides the underlying knowledge of culinary field. It surely helps the students preparing their studies, particularly for those who are unfamiliar with culinary area. By engaging those topics, the English lecturer applies them in English language skills. However, with the limitation of class meeting time, the expectation of this subject seems impossible to achieve. A large number of student, the students' motivation to learn English, and lack of material sources also become the main constrains of the ESP learning in this class. Lecturer would not have adequate time to give a vocabulary explanation and drilling. The students suppose to have their self-study outside the classroom to enrich the vocabulary in order to meet the class expectation at the end of semester. 
Table 2: English Lesson Topics in Culinary Program

\begin{tabular}{|c|c|c|}
\hline No & Topic & Subtopic \\
\hline 1 & Career in culinary & $\begin{array}{l}\text { Kitchen organization } \\
\text { Responsibilities }\end{array}$ \\
\hline 2 & Groceries & $\begin{array}{l}\text { Fruits and vegetables } \\
\text { Animal and dairy products } \\
\text { Condiments }\end{array}$ \\
\hline 3 & Kitchen Utensils & $\begin{array}{l}\text { Cooking utensils } \\
\text { Serving utensils } \\
\text { Eating utensils }\end{array}$ \\
\hline 4 & Cooking Techniques & \\
\hline 5 & Food Serving & $\begin{array}{l}\text { Appetizer } \\
\text { Main course } \\
\text { Dessert } \\
\text { Snack }\end{array}$ \\
\hline 6 & Authentic Food & $\begin{array}{l}\text { Continental food } \\
\text { Oriental food }\end{array}$ \\
\hline 7 & Cooking recipe & How to cook? \\
\hline
\end{tabular}

\section{Designing Android Vocabulary Application for Culinary Program}

Referring to the students' interests and learning constrains, the availability of complementary aid is required. Several main topics of the lesson in the class is adapted and becomes the content of the application. The objective is to provide enjoyable learning aid for the students so that they can do vocabulary self-study outside of classroom anytime and anywhere. The framework is combining vocabulary explanation equipped with image and sound, also the definition of word. Moreover, practice and exercise in a form of attractive vocabulary games is also executed.

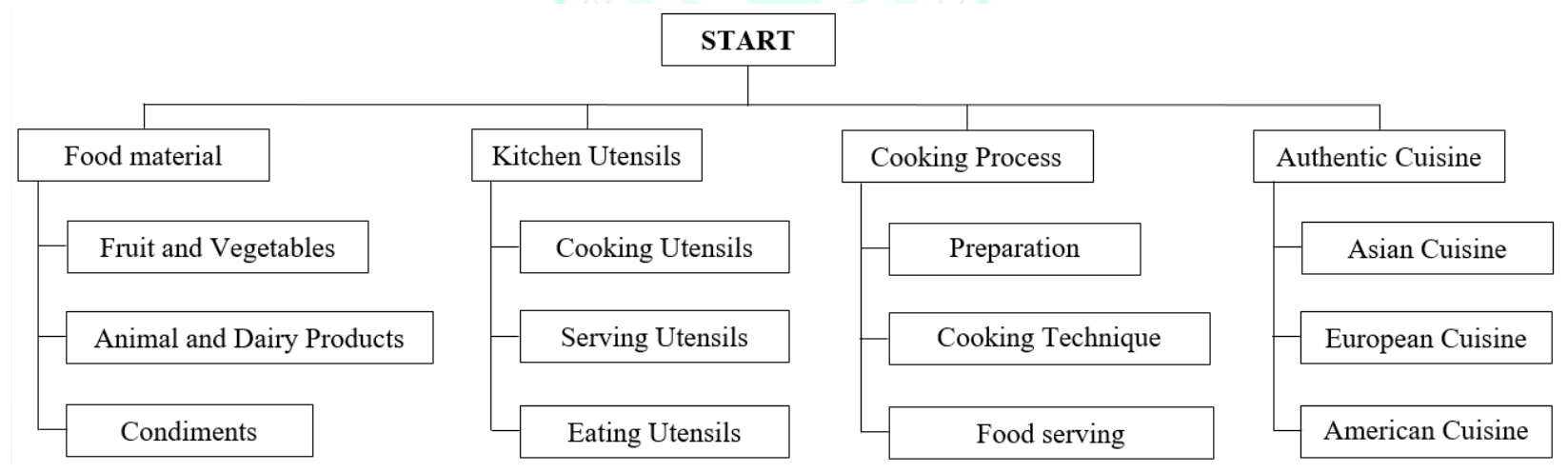

Figure 3: Application Topic Content

Figure 3 describes the topics and subtopics inserted in the application. There are four main topics; food material, kitchen utensils, cooking process, and authentic cuisine, with the three subtopics in each of them. There are 50 words alphabetically programmed in each subtopics with some features; image, phonetics transcription, pronunciation audio, and English definition as showed in Figure 4. In each topic, there are several exercises and games to test the user's mastery in vocabulary. Fill in the blanks, multiple choices, crossword puzzle, hangman, hidden objects in various level can be chosen for testing the vocabulary mastery. 


\title{
Chili
}

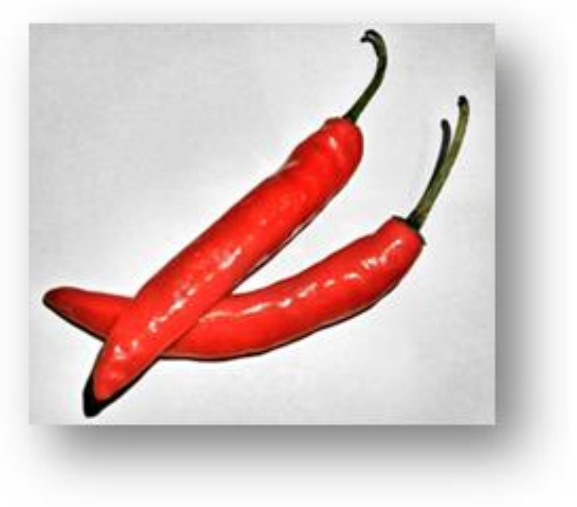

\author{
/'CHilē/ +1)) \\ A small hot-tasting pod of a \\ variety of capsicum, used in \\ sauces, relishes, and spice \\ powders. There are various \\ forms with pods of differing size, \\ color, and strength of flavor.
}

Figure 4: Example of Vocabulary Listed in the Application

\section{Conclusion}

Vocabulary is the first important step for learning language in order to achieve further comprehension in the communication. Intentional vocabulary learning is considered the right technique for foreign language learners the difficulties to understand and use the vocabulary in the right context. Regarding the obstacles of learning English in Culinary Education Program, the complimentary aid of English language learning is required to provide an effective learning. This research aims to design smartphone android application for culinary program students. The stages of the research are; (1) collecting data, (2) designing the application flow chart, and (3) designing the layout. It is expected to provide enjoyable learning aid for the students so that they can do vocabulary self-study outside of classroom anytime and anywhere.

For further study, the researcher can develop the application into ready to use application. Moreover, the evaluation of the application can be done to test its ability. Furthermore, the implementation of the application can also be conducted to find out its effectiveness. 


\section{References}

i. Ahmad, S., 2016. Importance of English Communication Skills. International Journal of Applied Research, 2(3), pp. 478-480.

ii. Alqahtani, M., 2015. The Importance of Vocabulary in Language Learning and How to be Taught. International Journal of Teaching and Education, 3(3), pp. 21-34.

iii. Bracaj, M., 2014. Teaching English for Specific Purposes and teacher training. European Scientific Journal, ESJ, 10(2).

iv. Braine, G., 2014. Teaching English to the world: History, curriculum, and practice. s.l.:Routledge.

v. Ciampa, K., 2014. Learning in a Mobile Age: an Investigation of Student Motivation. Journal of Computer Assisted Learning, 30(1), pp. 82-96.

vi. Ghanbaran, S. \& Ketabi, S., 2014. Multimedia Games and Vocabulary Learning. Theory and Practice in Language Studies, 4(3), p. 489.

vii. Huseyin, O., 2015. An Investigation of Preservice English Teachers' Perceptions of Mobile Assisted Language Learning. English Language Teaching, 8(2), p. 22.

viii. Kirovska-Simjanoska, D., 2017. Smartphones as Learning and Organizational Tools in the ESP Classroom. Journal of Teaching English for Specific and Academic Purposes , 5(2), pp. 321-332.

ix. Madarsara, F., Youhanaee, M., Barati, H. \& Nasirahmadi, A., 2015. Intentional vs. Incidental Vocabulary Learning through Games by Young EFL Persian Speakers. International Journal of Research Studies in Educational Technology, 4(1).

x. Marcellino, M., 2015. English Language Teaching in Indonesia: A Continuous Challenge in Education and Cultural Diversity. TEFLIN Journal, 19(1), pp. 57-69.

xi. Marwan, A., 2017. ESP Teaching Challenges in an Indonesian Vocational Higher Institution. The English Teacher, p. 12.

xii. Mattarima, K. \& Hamdan, A., 2016. The Teaching Constraints of English as a Foreign Language in Indonesia the Context of School based Curriculum. Sosiohumanika, 4(2).

xiii. Mindog, E., 2016. Apps and EFL: A Case Study on the Use of Smartphone Apps to Learn English by Four Japanese University Students. JALT CALL Journal, 12(1), pp. 3-22.

xiv. Mokhtar, A. et al., 2017. Vocabulary Learning Strategies of Adult ESL Learners. The English Teacher, p. 12.

xv. Nation, I., 2013. Learning Vocabulary in Another Language Google eBook. Cambridge: Cambridge University Press..

xvi. Panggabean, H., 2015. Problematic Approach to English Learning and Teaching: A Case in Indonesia. English Language Teaching, 8(3), p. 33.

xvii. Sekhar, G. \& Chakravorty, S., 2017. TESL/TEFL: Teaching English as a Second or Foreign Language. ACADEMICIA: An International Multidisciplinary Research Journal, 7(4), pp. 154-163.

xviii. Wu, Q., 2015. Designing a Smartphone App to Teach English (L2) Vocabulary. Computers \& Education, Volume 85, pp. 170-179.

xix. Zheng, D., Bischoff, M. \& Gilliland, B., 2015. Vocabulary Learning in Massively Multiplayer Online Games: Context and Action before Words. Educational Technology Research and Development, 63(5), pp. 771-790. 